\title{
ANALISIS PENGARUH TINGKAT INFLASI, TINGKAT SUKU BUNGA DAN NILAI TUKAR TERHADAP INDEKS HARGA SAHAM GABUNGAN (IHSG) DI BURSA EFEK INDONESIA (BEI) PERIODE 2013-2015
}

\author{
Daniar Primavistanti \\ daniarprima94@gmail.com \\ Universitas Ahmad Dahlan \\ Aftoni Sutanto \\ aftoni@yahoo.com \\ Universitas Ahmad Dahlan
}

\begin{abstract}
ABSTRAK
This research aimed to analyze and test the effect of inflation rates, interest rate and exchange rate on the stok price index at the stock exchange in 2013-2015. Independent variable used are inflation, interest rates, and exchange rates. While the dependent variable is the stock price index. The object of this research is in the market listed on the stock price index. The inflation rates, interest rates, and the exchange rate that are taken from Indonesian Bank. The analytical method used is the classic assumption test and regression test. Based on the survey result revealed that in partial inflation and the exchange rate does not significantaly influence the Stock Exchange Composite Index. While the variable interest rate significantly influence the Stock Exchange Composite Index. The test results simultaneosly show variable inflation, interest rates and exchange rates have an influence on the Stock Exchange Composite Index. The coefficient of determination was 28,3\%.
\end{abstract}

Keywords: Inflation Rates; Interest Rate; Exchange Rate; Composite Stock Price Index.

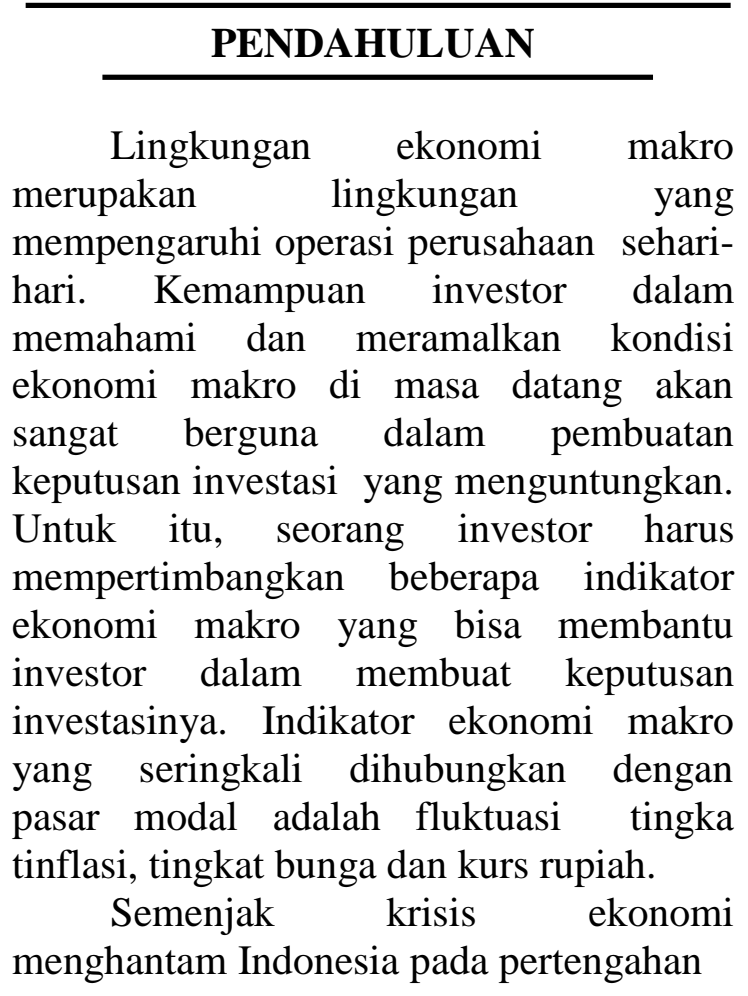

1997, kinerja pasar modal mengalami penurunan tajam bahkan diantaranya mengalami kerugian. Kondisi ini tentu akan mempengaruhi investor untuk melakukan investasi di pasar modal khususnya saham dan akan berdampak terhadap harga pasar saham di bursa. Dilanjutkan tahun 1998 yang merupakan awal runtuhnya perekonomian nasional Indonesia, ditandai dengan turunnya kepercayaan masyarakat terhadap perbankan Indonesia yang mengakibatkan hampir semua kegiata ekonomi terganggu. Selain itu krisis ekonomi juga menyebabkan variabel-variabel ekonomi, seperti suku bunga, inflasi, nilai tukar rupiah maupun pertumbuhan ekonomi mengalami perubahan yang cukup tajam. Suku bunga meningkat sampai mencapai angka $68,76 \%$ pertahun pada tahun 1998 , demikian juga inflasi mencapai angka 
$77 \%$ per tahun (Statistik Ekonomi Keuangan Indonesia, 1998).

Inflasi didefinisikan sebagai suatu gejala dimana tingkat harga umum mengalami kenaikan secara terus menerus (Nanga, 2001). Berdasarkan definisi tersebut, kenikan tingkat harga umum (general price level) yang terjadi sekali waktu saja, tidaklah dapat dikatakan sebagai inflasi. Tingkat inflasi yang tinggi biasanya dikaitkan dengan kondisi ekonomi yang terlalu panas (overheated). Artinya, kondisi ekonomi mengalami permintaan atas produk yang melebihi kapasitas penawaran produknya, sehingga harga-harga cenderung mengalami kenaikan. Inflasi yang terlalu tinggi juga akan menyebabkan penurunan daya beli uang (purchasing power of money). Disamping itu, inflasi yang tinggi juga bisa mengurangi tingkat pendapatan riil yang diperoleh investor dari investasinya.

Hooker (2004) menemukan bahwa tingkat inflasi mempengaruhi secara signifikan terhadap harga saham. Peningkatan inflasi secara relatif merupakan sinyal negatif bagi pemodal di pasar modal. Inflasi meningkatkan pendapatan dan biaya perusahaan. Jika peningkatan biaya produksi lebih tinggi dari peningkatan harga yang dapat dinikmati oleh perusahaan maka profitabilitas perusahaan akan turun. Jika profit yang diperoleh perusahaan kecil, hal ini akan mengakibatkan para investor enggan menanamkan dananya di perusahaan tersebut sehingga harga saham menurun.

Perkembangan inflasi dapat mendorong atau mengurungkan niat investor untuk menanamkan modalnya pada perusahaan yang terdaftar pada IHSG, karena trend inflasi yang berfluktuasi menunjukkan adanya ketidakstabilan tingkat inflasi di Indonesia. Kenaikan inflasi terakhir tahun 2014 mencapai $7,75 \%$. Inflasi akan cenderung meningkatkan biaya produksi dari perusahaan, sehingga keuntungan dari perusahaan akan lebih rendah, hal ini mengakibatkan para investor enggan menanamkan dananya di perusahaan tersebut sehingga menjadikan harga saham di bursa menjadi turun.

Tingkat suku bunga menyatakan tingkat pembayaran atas pinjaman atau investasi lain, di atas perjanjian pembayaran kembali, yang dinyatakan dalam presentase tahunan (Dornbusch, et.al., 2008). Suku bunga mempengaruhi keputusan individu terhadap pilihan membelanjakan uang lebih banyak atau menyimpan uangnya dalam bentuk tabungan. Suku bunga juga merupakan sebuah harga yang menghubungkan masa kini dengan masa depan, sebagaimana harga lainnnya maka tingkat suku bunga ditentukan oleh interaksi antara permintaan dan penawaran.

Tingkat bunga yang tinggi merupakan sinyal negatif terhadap harga saham. Tingkat suku bunga yang meningkat akan meningkatkan suku bunga yang diisyaratkan atas investasi pada suatu saham. Di samping itu, tingkat suku bunga yang meningkat bisa juga menyebabkan investor menarik investasinya pada saham dan memindahkannya pada investasi berupa tabungan atau deposito. Suku bunga yang makin tinggi memperlesu perekonomian, menaikkan biaya bunga dengan demikian menurunkan laba perusahaan dan menyebabkan para investor menjual saham dan mentransfer dana ke pasar obligasi.

Meningkatnya tingkat bunga secara langsung bisa meningkatkan beban bunga, tahun 2013 kenaikan tingkat suku bunga membuat IHSG menurun. Pada saat suku bunga stabil sebesar 5,75\%, IHSG mengalami kenaikan, saat tingkat suku bunga mengalami kenaikan $6,00 \%$ sampai $7,50 \%$ IHSG mengalami penurunan yang tidak stabil.

Selain inflasi dan suku bunga, variabel makro ekonomi yang turut mempengaruhi volatilitas harga saham adalah kurs atau nilai tukar. Kurs atau nilai tukar adalah harga-harga dari mata 
uang luar negeri (Dornbusch et.al., 2008). Kenaikan nilai tukar (kurs) mata uang dalam negeri disebut apresiasi atas mata uang (mata uang asing lebih murah, hal ini berarti nilai mata uang asing dalam negeri meningkat). Penurunan nilai tukar (kurs) disebut depresiasi mata uang dalam negeri (mata uang asing menjadi lebih mahal, yang berarti mata uang dalam negeri menjadi merosot).

Hubungan antara saham dan kurs yang didasarkan pada pendekatan keseimbangan portofolio. Para investor mengalokasikan kekayaan mereka diantara aset-aset alternatif termasuk mata uang domestik, sekuritas domestik maupun asing. Peran nilai tukar adalah untuk menyeimbangkan antara pemenuhan (supply) dan kebutuhan (demand) aset yang ada. Oleh karena itu setiap perubahan kebutuhan dan pemenuhan dari aset akan mengubah keseimbangan nilai tukar. Sebagai contoh, terjadinya penambahan harga saham domestik akan menambah kekayaan dan kebutuhan akan uang dan konsekuensinya tingkat suku bunga akan meningkat. Tingkat suku bunga pada gilirannya akan menaikkan modal asing dan hasilnya adalah peningkatan kurs domestik dan suatu peningkatan nilai tukar riil.

Bagi perusahaan yang aktif melakukan kegiatan ekspor dan impor kestabilan kurs menjadi hal penting. Sebab ketika nilai kurs terepresiasi dengan dollar Amerika Serikat, hal ini akan mengakibatkan barang impor akan menjadi mahal. Apabila sebagian perusahaan menggunakan barang impor maka hal ini bisa menigkatkan biaya produksi dan menurunnya tingkat keuntungan perusahaan. Hal ini mempengaruhi investor pada perusahaan tersebut. Secara umum, hal ini mendorong pelemahan IHSG di pasar modal.

Tujuan dari penelitian ini di antaranya: 1) untuk mengetahui pengaruh antara tingkat inflasi terhadap IHSG di BEI pada periode 2013-2015, 2) untuk mengetahui pengaruh antara tingkat suku bunga terhadap IHSG di BEI pada periode 2013-2015, 3) untuk mengetahui pengaruh antara nilai tukar terhadap IHSG di BEI pada periode 2013-2015 dan 4) untuk mengetahui pengaruh antara tingkat inflasi, tingkat suku bunga dan nilai tukar terhadap IHSG di BEI pada periode 2013-2015.

\section{REVIEW LITERATUR DAN HIPOTESIS}

\section{Landasan Teori}

1. Pasar Modal

Dalam arti sempit, pasar modal adalah suatu pasar (tempat) yang disiapkan guna memperdagangkan saham-saham, obligasi-obligasi dan jenis surat berharga lainnya dengan memakai jasa para perantara pedagang efek (Sunariyah, 2006).

2. Investasi

Investasi adalah penanaman modal untuk satu atau lebih aktiva yang dimiliki dan biasanya berjangka waktu lama dengan harapan mendapatkan keuntungan dimasa-masa yang akan datang. Keputusan penanaman modal tersebut dapat dilakukan oleh individu atau suatu entitas yang mempunyai kelebihan dana (Sunariyah, 2006).

3. Inflasi

Inflasi adalah suatu proses meningkatnya harga-harga secara umum dan terus-menerus berkaitan dengan mekanisme pasar yang dapat disebabkan oleh berbagai faktor antara lain konsumsi masyarakat yang meningkat, berlebihnya likuiditas di pasar yang memicu konsumsi atau bahkan spekulasi, termasuk juga akibat adanya ketidak lancaran distribusi barang.

\section{Suku Bunga}

Suku bunga didefinisikan kompensasi atau imbalan jasa atas 
pinjaman uang kepada pemberi pinjaman kepada peminjam atas manfaat ke depan dari investasi dari uang pinjaman tersebut.

5. Nilai Tukar

Menurut Musdholifah (2007), nilai tukar atau kurs adalah perbandingan antara harga mata uang suatu negara dengan mata uang negara lain.

6. Indeks Harga Saham

Indeks harga saham adalah suatu indikator yang menunjukkan pergerakan harga saham. Indeks berfungsi sebagai indikator tren pasar, artinya pergerakan indeks menggambarkan kondisi pasar pada suatu saat, apakah pasar sedang aktif atau lesu.

7. Indeks Harga Saham Gabungan

IHSG adalah suatu rangkaian informasi historis mengenai pergerakan harga saham gabungan, sampai tanggal tertentu. Indeks harga saham gabungan mencerminkan suatu nilai yang berfiungsi sebagai pengukuran kinerja suatu saham gabungan di bursa efek.

\section{Penelitian Terdahulu}

Witjaksono (2010) dalam

penelitiannya yang berjudul "Analisis Pengaruh Tingkat Suku Bunga SBI, Harga Minyak Dunia, HargaEmas Dunia, Kurs Rupiah, Indeks Nikkei 225 dan Indeks Dow Jones terhadap IHSG (studi kasus pada IHSG di BEI selama periode 2000-2009)" menunjukkn bahwa kurs rupiah berpengaruh negatif terhadap IHSG.

Novianto (2011) dalam penelitiannya menggunakan analisis berganda dimana, kurs rupiah, tingkat suku bunga, mempunyai pengaruh positif terhadap IHSG.

\section{Hipotesis}

H1: Terdapat pengaruh tingkat inflasi terhadap IHSG di BEI pada tahun 2013-2015.

$\mathrm{H} 2$ : Terdapat pengaruh tingkat suku bunga terhadap IHSG di BEI pada tahun 2013-2015.

H3: Terdapat pengaruh nilai tukar terhadap IHSG di BEI pada tahun 2013-2015.

H4: Terdapat pengaruh inflasi, tingkat suku bunga dan nilai tukar terhadap pergerakan IHSG di BEI tahun 2013-2015.

\section{METODE PENELITIAN}

\section{Definisi Operasional}

1. Variabel Independen

a. Inflasi

Inflasi didefinisikan sebagai suatu gejala dimana tingkat harga umum mengalami kenaikan secara terus menerus (Nanga, 2001).

b. Tingkat Suku Bunga

Suku bunga adalah harga dana yang dapat dipinjamkan (loanable funds), besarnya ditentukan oleh preferensi dan sumber pinjaman berbagai pelaku ekonomi di pasar (Noverika, 2010).

c. Nilai Tukar

Menurut Musdholifah (2007), nilai tukar atau kurs adalah perbandingan antara harga mata uang suatu negara dengan mata uang negara lain.

2. Variabel Dependen

Variabel dependen (Y) yang digunakan dalam penelitian ini adalah Indeks Harga Saham Gabungan (IHSG). Indeks Harga Saham Gabungan (IHSG) adalah suatu rangkaian informasi historis mengenai pergerakan harga saham gabungan, 
sampai tanggal tertentu. Indeks harga saham gabungan mencerminkan suatu nilai yang berfungsi sebagai pengukuran kinerja suatu saham gabungan di bursa efek.

\section{Uji Instrumen}

\section{Uji Asumsi Klasik}

a. Normalitas

Uji normalitas diperlukan untuk mengetahui alat analisis yang seharusnya digunakan parametik atau non parametik atau bisa dikatakan untuk mengetahui data penelitian tersebut berdistribusi normal atau tidak. Artinya jika ada berdistribusi normal maka penelitian ini menggunakan uji parametik, sebaliknya jika data merupakan distribusi tidak normal maka pengujian dengan uji non parametik dan data yang berdistribusi normal akan memperkecil kemungkinan terjadinya bias dan model regresi yang baik adalah jika data berdistribusi secara normal.

Untuk menguji apakah data itu termasuk dalam berdistribusi normal atau tidak, digunakan uji pengujian sampel Kolmogorovsmirnov, yaitu dengan membandingkan nilai probabilitas (p-value) dengan nilai probabilitas yang telah ditentukan yaitu $\alpha: 0,05$.

Probabilitas >0,05, maka data berdistribusi normal, sebaliknya

Probabilitas < 0,05 maka data tidak berdistribusi normal.

b. Autokorelasi

Menguji autokorelasi dalam
suatu model bertujuan untuk
mengetahui ada tidaknya korelasi
antara variable pengganggu pada
periode tertentu dengan variabel
sebelumnya (Sujarweni, 2007 :95).

Jika terjadi autokorelasi maka dinamakan ada penyakit autokorelasi. Tentu saja model regresi yang baik adalah regresi yang terbebas dari autokorelasi.

Teknik pengujian autokorelasi adalah durbin waston-test. Dengan pengambilan keputusan dapat dilakukan dengan membandingkan nilai uji D-W (d) dengan nilai tabel D-W (dL dan dU). Dengan kriteria jika du $<$ d hitung $<4-$ du, maka tidak terjadi autokorelasi.

c. Heteroskedastisitas

Heteroskedastisitas adalah satu keadaan dimana varian dari kesalahan pengganggu tidak konstan untuk semua nilai variabel bebas (Suprapto, 1983). Uji Heteroskedastisitas bertujuan untuk menguji apakah dalam regresi terjadi ketidaksamaan variabel dari residual satu pengamatan ke pengamatan yang lain tetap, maka disebut homoskedastisitas dan jika berbeda disebut heteroskedastisitas. Model regresi yang baik adalah tidak terjadi heteroskedastisitas.

d. Multikolinieritas

Uji multikolinieritas digunakan untuk menguji apakah model regresi ditemukan adanya korelasi antara variabel independen. Bila variabel-variabel berkorelasi secara sempurna maka disebut multikolienaritas sempurna (perfect multicollinearty).

Untuk menguji asumsi multikolinearitas dapat dilakukan dengan matriks korelasi dengan melihat VIF dan nilai tolerance. Nilai vut off yang umum dipakai untuk menunjukkan adanya multikolinearitas adalah nilai tolerance $<0,10$ dan VIF $>10$. 


\section{Teknik Analisis Data}

1. Analisis Regresi Berganda

Analisis regresi merupakan suatu metode yang digunakan untuk menganalisis hubungan antara variabel. Hubungan terikat $\mathrm{Y}$ dengan satu atau lebih variabel bebas $(\mathrm{X} 1, \mathrm{X} 2, \mathrm{X} 3, \ldots$, $\mathrm{Xn}$ ) untuk dapat menganalisis variabel independen terhadap dependen. Secara umum ditunjukkan dengan persamaan berikut:

$\mathrm{Y}=\alpha+\mathrm{b} 1 \mathrm{X} 1+\mathrm{b} 2 \mathrm{X} 2+\mathrm{b} 3 \mathrm{X} 3+\mathrm{b} 4 \mathrm{X} 4$

Keterangan :

$\mathrm{Y}=$ Variabel IHSG

$\mathrm{X} 1=$ Variabel Inflasi

$\mathrm{X} 2=$ Variabel Suku bunga

$\mathrm{X} 3=$ Variabel Nilai Tukar

$\mathrm{X} 4=$ Variabel Pengangguran

$\alpha=$ Variabel konstanta

b1, b2, b3, b4 = Koefisien Regresi

\section{Uji Hipotesis}

\section{Uji Parsial (Uji T)}

Uji $T$ digunakan untuk menunjukkan seberapa jauh pengaruh satu variabel independen secara individual dalam menerangkan variasi variabel dependen. Langkah-langkah yang dilakukan untuk mengetahui pengaruh masing-masing variabel independen terhadap variabel dependen ini yaitu :

a. Merumuskan Hipotesis

b. Menentukan tingkat signifikasi $(\alpha)$ sebesar 5\%

c. Menentukan criteria penolakan hipotesis, Ha ditolak jika prob. Sig $<0.05$.

\section{Uji Simultan (Uji F)}

$$
\text { Uji F digunakan untuk }
$$
menunjukkan apakah semua variabel bebas/independen yang dimasukkan dalam model mempunyai pengaruh secara bersama-sama terhadap variabel terikat/ dependen. Pengujian ini dimaksudkan untuk mengetahui apakah variabel independen (inflasi, suku bunga, kurs dan pengangguran) secara serentak atau bersama-sama mempunyai hubungan yang signifikan dengan variabel independen (IHSG).

Perhitungan nilai $F$ hitung dilakukan dengan bantuan komputer dengan progam SPSS. Pengambilan keputusan ini didasarkan pada perbandingan $\mathrm{F}$ hitung dengan $\mathrm{f}$ tabel, maka keputusan adalah menerima hipotesis (H0) artinya secara statistic dapat dibuktikan bahwa semua variabel independen secara bersamasama tidak berpengaruh terhadap perubahan nilai variabel dependen (Y). Sedangkan jika $\mathrm{F}$ hitung lebih besar dari f tabel, maka keputusan adalah menolak hipotesis (H0), artinya secara statistik dapat dibuktikan bahwa semua variabel independen secara bersama-sama berpengaruh terhadap perubahan nilai variabel dependen.

\section{Uji Koefisien Determinasi}

Koefisien determinasi digunakan untuk mengukur seberapa jauh kemampuan model dalam menerangkan variasi variabel dependen. Koefisien determinasi adalah di antara nol dan satu, jika nilai kecil atau mendekati nol maka variasi variabel dependen amat terbatas. Sedangkan jika nilai besar atau mendekati satu maka hampir semua informasi yang dibutuhkan untuk memprediksi variabel dependen. Nilai Rsquare dikatakan baik jika di atas 0,5 karena $\mathrm{R}$-square berkisar antara 0 sampai 1, jika baik berarti variabel independen berpengaruh terhadap variabel dependen sedangkan sisanya akan dipengaruhi oleh variabel lain yang tidak dijelaskan dalam penelitian ini. 


\section{HASIL PENELITIAN DAN PEMBAHASAN}

\section{Hasil Analisis Deskriptif}

\begin{tabular}{|l|r|r|r|r|r|r|}
\hline & \multicolumn{1}{|c|}{ D } & Minimum & Maximum & \multicolumn{1}{c|}{ Sum } & \multicolumn{1}{c|}{ Mean } & Std. Deviation \\
\hline Inflasi \% & 36 & -.36 & 3.29 & 19.54 & .5428 & .73683 \\
suku_bunga \% & 36 & .058 & .078 & 2.580 & .07167 & .006735 \\
nilai_tukar & 36 & 10186.65 & 14896.10 & 446606.15 & 12405.7264 & 1358.81254 \\
insg & 36 & 4195.09 & 5518.67 & 173027.03 & 4806.3064 & 362.58885 \\
Valid N (listwise) & 36 & & & & & \\
\hline
\end{tabular}

1. Tingkat inflasi mempunyai nilai minimum sebesar $-0,36 \%$ dan nilai maksimum sebesar 3,29\%. Jumlah tingkat inflasi adalah19,54\%. Ratarata tingkat inflasi adalah $0,5428 \%$ dengan standar deviasi 0,73683.

2. Tingkat suku bunga mempunyai nilai minimum sebesar $0,58 \%$ dan nilai maksimum sebesar $0,78 \%$. Jumlah tingkat suku bungaadalah 2,580\%. Rata-rata tingkat suku bunga adalah $0,0717 \%$ dengan standar deviasi 0,006735 .

3. Nilai tukar mempunyai nilai minimum sebesar 10186,65 dan nilai maksimum sebesar 14896,10. Jumlah tingkat nilai tukar adalah 446606,15. Rata-rata nilai tukar adalah 12405,7264 dengan standar deviasi 1358,81254 .

4. Indeks harga saham gabungan (IHSG) mempunyai nilai minimum sebesar 4195,09 dan nilai maksimum sebesar 5518,67. Jumlah indeks harga saham gabungan (IHSG) adalah 173027,03. Rata-rata indeks harga saham gabungan adalah 4806,3064 dengan standar deviasi 362,58885.

\section{Hasil Penelitian}

1. Hasil Uji Asumsi Klasik

a. Normalitas

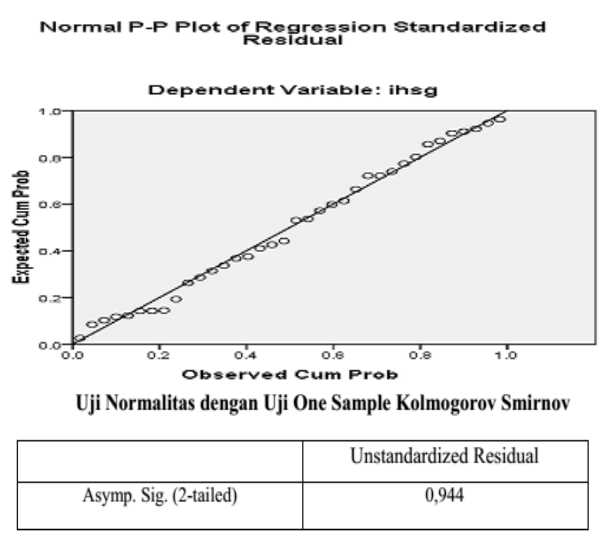

Pada dasarnya normalitas sebuah data dapat dikenali atau dideteksi dengan melihat persebaran data (titik) pada sumbu diagonal dari grafik Histogram dan residualnya. Data dikatakan berdistribusi normal, jika data menyebar disekitar garis diagonal Unstandardized Residual Asymp. Sig. (2-tailed) 0,944 dan mengikuti arah garis diagonal atau grafik histogramnya. Sebaliknya data dikatakan tidak berdistribusi normal, jika data menyebar jauh dari arah garis atau tidak mengikuti diagonal atau grafik histogramnya.

Hasil pengujian normalitas dengan menggunakan One Sample Kolmogorov-Smirnov menunjukkan uji normalitas mempunyai tingkat signifikasi sebesar 0,944 . Nilai Signifikasi tersebut di atas 0,05 . Hal ini berarti data yang digunakan dalam penelitian ini berdistribusi normal.

b. Autokorelasi

Hasil Uji Autokorelasi

\begin{tabular}{|c|c|c|c|}
\hline Model & Durbin-Watson & $\mathrm{dL}$ & $\mathrm{dU}$ \\
\hline 1 & 1,752 & 1,2358 & 1,7245 \\
\hline
\end{tabular}

Berdasarkan hasil pengujian pada tabel di atas, diperoleh nilai Durbin Watson sebesar 1,752. Sedangkan nilai dL dan dU dari tabel Durbin Watson dengan alpha $5 \%, \mathrm{n}=36$ dan $\mathrm{k}=4$ menunjukkan 
nilai $\mathrm{dL}=1,2358$ dan $\mathrm{dU}=1,7245$. Diperoleh nilai 4-dL $=2,7642$ dan nilai $4-\mathrm{dU}=2,2755$, sehingga dapat digambar sebagai berikut :

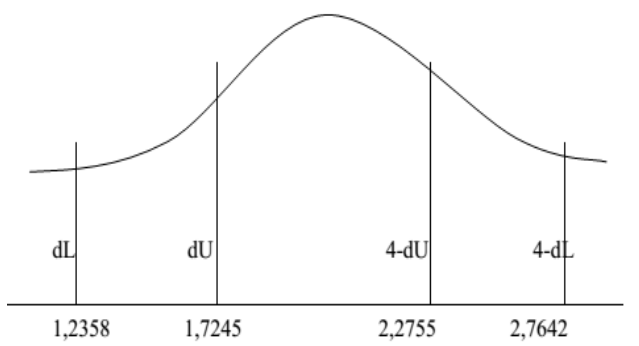

Oleh karena nilai DW 1,752 lebih besar dari batas atas $(\mathrm{dU})=$ 1,7245 dan kurang dari 4-dU $(2,2755)$ atau terletak antara 1,7245 dan 2,2755 maka dapat disimpulkan bahwa tidak terdapat autokorelasi pada model regresi.

c. Heteroskedastisitas Hasil Uji Heteroskedastisitas

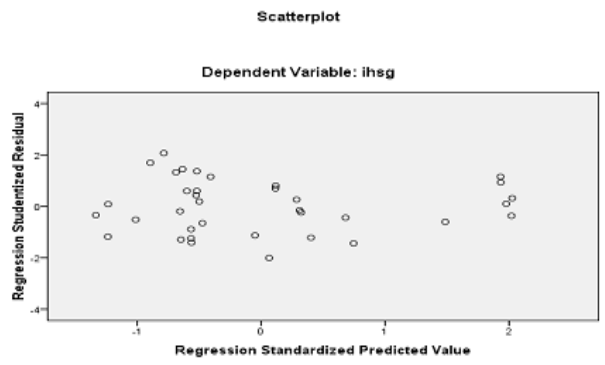

Dari grafik scatterplots terlihat bahwa titik-titik data menyebar di atas dan di bawah atau disekitar angka 0 , titik-titik tidak membentuk pola bergelombang melebar kemudian menyempit dan melebar kembali. Sehingga dapat disimpulkan bahwa model regresi yang digunakan tidak terjadi heteroskedastisitas.

d. Multikolinieritas

Hasil Uji Multikolinearitas

\begin{tabular}{|l|c|c|c|}
\hline \multicolumn{1}{|c|}{$\begin{array}{c}\text { Variabel } \\
\text { Independen }\end{array}$} & \multicolumn{2}{|c|}{ Collinearity Statistics } & \multirow{2}{*}{ Kesimpulan } \\
\cline { 2 - 3 } & Tolerance & VIF & \\
\hline Inflasi & 0,914 & 1,094 & Tidak ada multikolinearitas \\
Suku Bunga & 0,728 & 1,373 & Tidak ada multikolinearitas \\
Nilai Tukar & 0,758 & 1,319 & Tidak ada multikolinearitas \\
& & & \\
\hline
\end{tabular}

Berdasarkan tabel di atas, terlihat bahwa hasil perhitungan tolerance menunjukkan tidak ada variabel independen yang memiliki nilai tolerance kurang dari 0,10 yang berarti tidak ada korelasi antara variabel independen. Hasil perhitungan nilai variance inflation factor (VIF) juga menunjukkan hal yang sama yaitu tidak ada satu variabel independen yang memiliki nilai VIF lebih dari 10. Jadi dapat disimpulkan bahwa tidak ada multikolinearitas antara variabel independen dalam model regresi.

2. Hasil Uji Regresi Linier Berganda

Hasil Analisis Regresi Linear Berganda

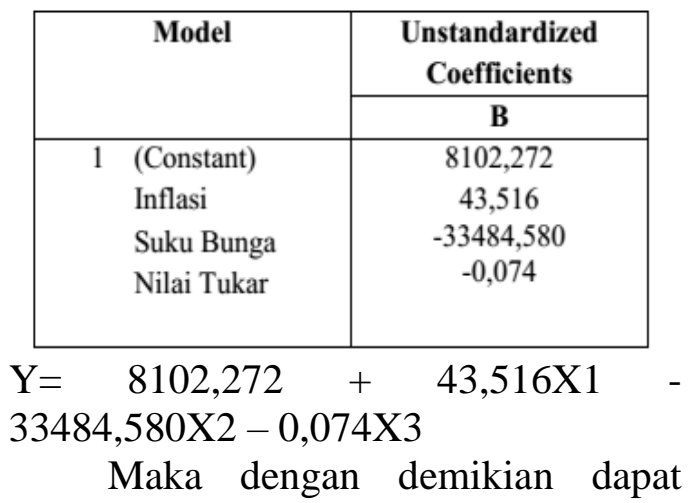
dianalisis sebagai berikut :

a. Nilai konstanta adalah positif sebesar 8102,272 mengandung artibahwa jika variabel bebas (tingkat inflasi, tingkat suku bunga, nilai tukar rupiah dan tingkat pengangguran) bernilai nol maka IHSG di BEI adalah 8102,272 persen.

b. Nilai koefisien regresi variabel inflasi sebesar 43,516. Nilai koefisien regresi yang positif tersebut berarti jika variabel tingkat inflasi naik satu satuan, maka peningkatan IHSG sebesar 43,516persen.

c. Nilai koefisien regresi tingkat suku bunga sebesar -33484,580. Nilai koefisien regresi yang negatif tersebut berarti jika variabel tingkat suku bunga naik satu satuan maka akan terjadi penurunan IHSG sebesar -33484,580 persen.

d. Nilai koefisien regresi nilai tukar sebesar-0,074. Nilai koefisien regresi yang negatif tersebut berarti 
jika variabel tingkat nilai tukar naik satu satuan maka akan terjadi penurunan IHSG sebesar $-0,074$ persen.

\section{Hasil Uji Parsial (Uji T)}

\begin{tabular}{|ll|r|r|}
\multicolumn{1}{|c|}{ Uji T } \\
\hline 1 Model & \multicolumn{1}{c|}{ T } & \multicolumn{1}{c|}{ Sig. } \\
\hline \multicolumn{1}{|c|}{ Inflasi } & 7,622 & 0,000 \\
& suku_bunga & 0,565 & 0,576 \\
nilai tukar & $-3,545$ & 0,001 \\
& $-1,616$ & 0,116 \\
& & \\
& & \\
\end{tabular}

a. Dari tabel uji $\mathrm{t}$ yang telah dilakukan pada variabel tingkatinflasi, diketahui bahwa nilai signifikasi > alpha $(0,576>0,05)$ artinya 0,576 lebih besar daripada 0,05 yang berarti tidak signifikan. Dengan demikian dapat disimpulkan bahwa variabel tingkatinflasi tidak berpengaruh signifikan terhadap IHSG.

b. Dari tabel uji t yang telah dilakukan pada variabel tingkat suku bunga, diketahui bahwa nilai signifikasi < alpha $(0,001<0,05)$ artinya 0,001 lebih kecil daripada 0,05 yang berarti signifikan. Dengan demikian dapat disimpulkan bahwa variabel tingkat suku bunga berpengaruh signifikan terhadap IHSG.

c. Dari tabel uji t yang telah dilakukan pada variabel nilai tukar, diketahui bahwa nilai signifikasi < alpha $(0,116>0,05)$ artinya 0,116 lebih besar daripada 0,05 yang berarti signifikan. Dengan demikian dapat disimpulkan bahwa variabel nilai tukar tidak berpengaruh signifikan terhadap IHSG.

\section{Hasil Uji Simultan (Uji F)}

Uji F

\begin{tabular}{|cl|l|l|}
\hline Model & F & Sig. \\
\hline 1 & $\begin{array}{l}\text { Regression } \\
\text { Residual }\end{array}$ & 4,204 & $0,006^{\mathrm{a}}$ \\
\hline
\end{tabular}

Dari hasil output di atas dapat dilihat dimana $\mathrm{F}$ hitung $>\mathrm{f}$ tabel $(4,204$ $>2,68$ ) dengan tingkat signifikan 0,006 yaitu yang berarti $<0,05$. Berdasarkan cara pengambilan keputusan uji $\mathrm{F}$ dalam analisis regresi dapat disimpulkan bahwa inflasi, suku bunga dan nilai tukar berpengaruh signifikan terhadap IHSG.

\section{Hasil Uji Koefisien Determinasi}

\section{Koefisien Determinasi}

\begin{tabular}{|c|c|}
\hline Model & R Square \\
\hline 1 & 0,283 \\
\hline
\end{tabular}

Besarnya koefisien determinasi (R2) adalah 0,362 yang berarti bahwa pengaruh dari tingkat inflasi, tingkat suku bunga dan nilai tukar rupiah sebesar 28,3\%. Sedangkan sisanya sebesar $71,7 \%$ dipengaruhi oleh faktorfaktor lain di luar model penelitian ini.

\section{Pembahasan}

1. Berdasarkan uji regresi linier berganda diperoleh konstanta sebesar 7,622 dengan tanda positif yang berarti bahwa IHSG akan mengalami perubahan, walaupun tidak dipengaruhi oleh inflasi, suku bunga dan nilai tukar.

2. Berdasarkan t-test diperoleh hasil bahwa secara parsial atau secara sendiri-sendiri variabel independen terhadap variabel dependen:

a. Pengaruh tingkat inflasi terhadap IHSG

Variabel independen tingkat inflasi tidak berpengaruh secara signifikan terhadap variabel dependen (IHSG) berarti H0 diterima dan Ha ditolak, karena nilai signifikasi $\mathrm{t}>$ taraf signifikan yang digunakan yaitu $5 \% \quad(0,576>0,05)$. Hasil ini mengindikasikan bahwa besar kecilnya inflasi pada masa penelitian tidak berdampak besar pada naik turunnya harga saham di BEI. Jika inflasi tinggi misalnya, 
akan mengakibatkan turunnya kepercayaan investor terhadap kondisi pasar modal sehingga akibatnya para investor akan melakukan penarikan dananya dalam investasi yang membuat nilai saham menjadi turun.

b. Pengaruh tingkat suku bunga terhadap IHSG.

Variabel independen tingkat suku bunga berpengaruh negatif signifikan terhadap variabel dependen (IHSG) berarti H0 ditolak dan Ha diterima, karena nilai signifikasi $\mathrm{t}<$ taraf signifikan yang digunakan yaitu $5 \%(0,001<0,05)$. Hasil ini mengindikasikan bahwa semakin tinggi tingkat suku bunga maka harga saham cenderung semakin menurun yang berakibat menurunnya IHSG.

c. Pengaruh nilai tukar terhadap IHSG. Variabel independen nilai tukar berpengaruh negatif signifikan terhadap variabel dependen (IHSG) berarti H0 ditolak dan Ha diterima, karena nilai signifikasi $\mathrm{t}>$ taraf signifikan yang digunakan yaitu $5 \%$ $(0,116>0,05)$. Hasil ini mengindikasikan nilai tukar tidak berpengaruh terhadap IHSG.

\section{KESIMPULAN DAN SARAN}

\section{Kesimpulan}

1. Secara parsial penelitian ini menunjukkan bahwa variabel inflasi dan nilai tukar tidak berpengaruh signifikan, variabel suku bunga berpengaruh signifikan.

2. Secara simultan, hasil penelitian ini menunjukkan bahwa inflasi, suku bunga dan nilai tukar secara bersamaan berpengaruh signifikan terhadap IHSG di BEI. Hal ini mengidentifikasikan bahwa H0 ditolak dan Ha diterima.

\section{Saran}

1. Diharapkan untuk penelitian selanjutnya, menambah variabel independen yang digunakan untuk menilai pengaruh variabel independen terhadap variabel dependen.

2. Diharapkan untuk peneliti selanjutnya menambah periode penelitian, sehingga objek penelitian lebih luas dan hasil yang diharapkan akan lebih baik lagi.

\section{DAFTAR PUSTAKA}

Nanga, Muana. (2001). Teori Makro Ekonomi. Jakarta: Rajawali Press.

Noverika, Reny. (2010). Faktor-faktor yang Mempengaruhi Indeks Harga Saham di Bursa Efek Indonesia Periode Tahun 2005-2009. Skripsi (tidak dipublikasikan). Yogyakarta: Universitas Ahmad Dahlan

Novianto, Aditya. (2011). Analisis Pengaruh Nilai Tukar (Kurs) Dolar Amerika/ Rupiah (US\$/Rp), Tingkat Suku Bunga SBI, Inflasi dan Jumlah Uang yang Beredar (M2) terhadap Indeks Harga Saham Gabungan (IHSG) di Bursa Efek Indonesia (BEI) Periode 19992010. Skripsi (di publikasikan). Semarang: Universitas Diponegoro.

Sujarweni, V. Wiratna. (2007). Panduan Mudah Menggunakan SPSS \& Contoh Penelitian Bidang Ekonomi. Cetakan Pertama. Ardana Media.

Sunariyah. (2006). Pengetahuan Pasar Modal. Edisi Kelima. Yogyakarta: UPP STIM YKPN.

Witjaksono, Ardian Agung. (2010). Analisis Pengaruh Tingkat Suku Bunga SBI, Harga Minyak Dunia, Harga Emas Dunia, Kurs Rupiah, Indeks Nikkei 225, dan Indeks 
Dow Jones terhadap IHSG".

Skripsi (dipublikasikan). Universitas

Diponegoro Semarang. 